\title{
Sikap Siswa pada Pembelajaran Matematika: Ditinjau dari Jenis Kelamin
}

\author{
Arif Hidayad \\ STKIP Taman Siswa Bima \\ arif.hidayad88@gmail.com
}

\begin{abstract}
ABSTRAK
Penelitian ini bertujuan untuk mendeskripsikan sikap siswa SMP dalam pembelajaran matematika yang ditinjau dari aspek jenis kelamin. Aspek jenis kelamin merupakan salah satu faktor yang dapat dikatakan mempengaruhi sikap dan kecendrungan siswa dalam belajar matematika. Siswa yang memilki sikap positif merupakan pertanda awal yang baik bagi proses belajar siswa tersebut. Pengungkapan sikap siswa dalam pembelajaran matematika ini menggunakan angket skala sikap yang berjumlah 32 butir yang terdiri dari 3 dimensi sikap yang terpecah menjadi 8 indikator sikap yang diukur. Angket tersebut diberikan kepada 72 siswa masing-masing 36 siswa laki-laki dan perempuan. Data dianalisis secara statistic deskriptif melalui perhitungan rata-rata dan simpangan baku dan dikonsultasikan dengan tabel pedoman penilaian untuk memperoleh kriteria sikap siswa secara individu. Hasil penelitian menunjukkan bahwa, dari 8 indikator sikap yang diukur, siswa laki-laki mengungguli siswa perempuan yaitu sebanyak 5 indikator sikap, sisanya sebanyak 3 indikator sikap diungguli siswa perempuan.
\end{abstract}

Kata Kunci: Sikap, Siswa SMP, Pembelajaran Matematika, Jenis Kelamin.

\section{PENDAHULUAN}

\section{Sikap}

Aiken (1980:2) secara konseptual menyatakan sikap merupakan kecendrungan individu dalam merespon secara positif atau secara negatif pada objek tertentu, situasi, konsep, atau orang. Sikap memiliki dimensi kognitif (kepercayaan atau ilmu pengetahuan), afektif (emosional, motivasi) dan performa (tingkah laku atau kecendrungan tingkah laku). Sikap adalah status mental seseorang yang membawa seseorang terhadap objek yang dihadapinya. Berkowitz (Azwar, 2013) ada tiga kerangka pemikiran yang mendefinisikan sikap. Pertama, para ahli psikologi seperti Louis Thurstone, Rensis Likert dan Charles Osgood menyatakan sikap adalah suatu bentuk evaluasi atau reaksi perasaan. Sikap seseorang terhadap suatu objek merupakan perasaan mendukung ataupun tidak mendukung pada objek tersebut. Secara spesifik, Thurstone sendiri memformulasikan sikap sebagai 'derajat afek positif atau afek negatif terhadap suatu objek psikologis'. Kedua, adalah pemikiran oleh Chave, Bogardus, LaPierre, Mead, dan Gordon Allport menyatakan sikap merupakan semacam kesiapan untuk bereaksi terhadap suatu objek dengan cara-cara tertentu. Sedangkan Allen, Guy, dan Egley mendefinisikan sikap sebagai suatu pola prilaku, tendensi atau kesiapan antisipatif, predisposisi untuk menyesuaikan diri dengan prilaku sosial, atau secara sederhana, sikap adalah respons terhadap stimuli sosial yang telah terkondisikan. Kelompok pemikiran yang ketiga adalah kelompok yang berorientasi pada skema triadic (triadic scheme). Secord dan Backman, misalnya mendefinisikan sikap sebagai 'keteraturan tertentu dalam hal perasaan (afeksi), pemikiran (kognisi), dan predisposisi tindakan (konasi) seseorang terhadap suatu aspek di lingkungan sekitarnya.

Dalam pelaksanaanya sikap seseorang/individu dipengaruhi oleh dua faktor yang secara umum yaitu faktor lokal dan faktor global pada diri individu. Faktor lokal berasal dari dalam diri individu sendiri seperti; reaksi emosional, kecemasan, sedangkan faktor global sendiri adalah yang berasal dari luar pribadi individu seperti kontek sosial dimana ia berada (Gomes, 2001). Faktor-faktor yang mempengaruhi pribadi individu tersebut akan membentuk suatu karakter. Karakter yang berkaitan dengan sikap adalah karakteristik afektif. Inti dari slogan tersebut adalah bahwa kemampuan afektif itu sangat penting. 


\section{Sikap Siswa dalam Pembelajaran Matematika}

Beberapa ahli memberikan pandangan tentang pentingnya kemampuan afektif dalam individu seseorang, diantaranya: (Popham, 1995) menganggap variabel afektif memiliki hubungan yang signifikan terhadap variabel kognitif. Afektif setidaknya sangat penting dalam pembelajaran di sekolah. Selain itu, motivasi dan peran keinginan merupakan pondasi dalam pembelajaran. Apabila siswa tidak mau belajar, maka mereka tidak akan terpelajarkan. Apabila mereka merasa tidak dapat belajar, maka mereka tidak akan terpelajarkan. Keinginan dan motivasi bukan merupakan karakter prestasi akademik, melainkan karakteristik afektif. Ilmu pengetahuan adalah kekuatan tetapi karakter adalah lebih baik (Stiggins, 2005).

Pembelajaran matematika hendaknya mampu merangsang siswa untuk bersikap serta berpikir kritis dalam memahami berbagai permasalahan. (Mariamah, 2017) dengan belajar matematika, maka siswa dapat berpikir kritis dan terampil berhitung serta memiliki kemampuan mengaplikasikan konsep dasar matematika pada mata pelajaran lain maupun pada matematika itu sendiri dan dalam kehidupan sehari-hari. Namun, pembelajaran matematika merupakan pembelajaran yang dirasa sulit oleh kebanyakan individu (siswa) sehingga pada umumnya siswa menunjukkan sikap yang negatif. Menurut Sidiq (Kartono, 2014), sifat negatif tersebut muncul sebagai akibat dari: 1) persepsi umum tentang sulitnya matematika berdasar pendapat orang lain; 2) pengalaman belajar di kelas yang diakibatkan proses pembelajaran yang kurang menarik hati peserta didik; 3) pengalaman di kelas sebagai hasil perlakuan guru (contohnya mencemooh); 4).persepsi yang terbentuk oleh ketidak berhasilan mempelajari matematika. Apabila siswa memiliki sikap negatif terhadap matematika maka dapat dikatakan bahwa kondisi afektif mereka untuk kegiatan pembelajaran matematika terganggu (Kartono, 2014). Kondisi tersebut setidaknya berbeda pada setiap diri individu (siswa), terutama pada pembelajaran matematika sekolah. Perbedaan kondisi afektif yang dimiliki setiap siswa dapat dipengaruhi beberapa faktor, diantaranya adalah jenis kelamin. Oleh karena itu, peneliti bermaksud untuk melakukan penelitian tentang sikap siswa dalam pembelajaran matematika ditinjau dari jenis kelamin. Hasil penelitian ini diharapkan mampu memberikan informasi tentang perbedaan sikap siswa dalam pembelajaran matematika pada siswa laki-laki dan perempuan.

\section{Dimensi Sikap Siswa Dalam Pembelajaran Matematika}

Ada sebanyak 3 dimensi sikap siswa dalam pembelajaran matematika dan terbagi dalam 8 indikator sikap yang diukur. Berikut tabel dimensi dan indikator sikap yang diukur dalam pembelajaran matematika siswa (Hidayad, 2017).

Tabel 1. Dimensi sikap siswa dalam pembelajaran matematika

\begin{tabular}{|c|c|c|c|c|}
\hline No & Dimensi & No & Indikator & $\begin{array}{c}\text { Jumlah } \\
\text { Butir }\end{array}$ \\
\hline \multirow{2}{*}{1} & \multirow{2}{*}{ Jujur (JJR) } & 1 & Atentif & 4 \\
\hline & & 2 & Jujur & 3 \\
\hline \multirow[b]{3}{*}{2} & \multirow{3}{*}{$\begin{array}{l}\text { Interaksi } \\
\text { Lingkungan } \\
\text { (ILN) }\end{array}$} & 3 & Efisien & 3 \\
\hline & & 4 & Percaya Diri & 5 \\
\hline & & 5 & $\begin{array}{l}\text { Interaksi } \\
\text { dengan } \\
\text { Lingkungan }\end{array}$ & 6 \\
\hline \multirow{3}{*}{3} & \multirow{3}{*}{ Serius (SRS) } & 6 & Kritis & 4 \\
\hline & & 7 & Teliti & 3 \\
\hline & & 8 & Telaten & 4 \\
\hline & \multicolumn{3}{|c|}{ Total } & 32 \\
\hline
\end{tabular}

Ketiga dimensi tersebut merupakan inti dari penyusunan butir instrumen pengumpul data. Instrumen pengumpul data berbentuk skala Likert yang terdiri dari 4 pilihan jawaban pada tiap butirnya. Pilihan jawaban berupa "Sangat Setuju=4 atau 1", "Setuju=3", "Kurang Setuju=2 atau 3" dan "Tidak Setuju=1 atau 4". Dari 32 butir instrumen terdapat 6 butir instrumen yang berupa pernyataan negatif, sedangkan 26 butir merupakan pernyataan positif. Analisis hasil penilaian siswa menggunakan pedoman kriteria penilaian skala sikap pada siswa oleh (Mardapi, 2008).

\section{METODE PENELITIAN}

Penelitian ini berjenis penelitian kualitatif dekriptif yaitu penelitian yang tidak menguji hipotesis, melainkan langsung memaparkan hasil penelitian berdasarkan data yang diperoleh. 
Populasi penelitian adalah siswa SMP kelas VIII yang berjumlah 125 siswa, sedangkan sampel penelitian adalah sebanyak 72 siswa yang diambil dengan teknik purposive dan simple random sampling. Sampel masing-masing berjumlah 36 siswa perempuan dan 36 siswa laki-laki. Data diperoleh dengan cara membagikan angket skala sikap kepada masing-masing sampel sebanyak satu kali. Data dianalisis menggunakan teknik statistik deskriptif yaitu menghitung skor total tiap siswa, nilai rata-rata dan simpangan baku, selanjutnya nilai-nilai tersebut dikonsultasikan dengan tabel kriteria penilaian sikap siswa seperti pada tabel 2 .

\begin{tabular}{ccl}
\multicolumn{3}{c}{ Tabel 2. Kriteria Penilaian Sikap Siswa } \\
\hline No & Skor Siswa & \multicolumn{1}{c}{ Kriteria } \\
\hline 1 & $\mathrm{X} \geq \bar{X}+1 . \mathrm{SBx}$ & $\begin{array}{l}\text { Sangat positif/ } \\
\text { sangat tinggi }\end{array}$ \\
\hline 2 & $\bar{X}+1 . \mathrm{SBx}>\mathrm{X} \geq \bar{X}$ & Positif/tinggi \\
\hline 3 & $\bar{X}>\mathrm{X} \geq \bar{X}-1 . \mathrm{SBx}$ & Negatif/rendah \\
\hline 4 & $\mathrm{X}<\bar{X}-1 . \mathrm{SBx}$ & $\begin{array}{l}\text { Sangat negatif/ } \\
\text { sangat rendah }\end{array}$ \\
\hline
\end{tabular}

\section{Keterangan:}

$\mathrm{X}$ : Skor total tiap siswa

$\bar{X}$ : Rerata skor siswa dalam satu kelas

SBx : Simpangan Baku skor keseluruhan siswa dalam satu kelas.

\section{HASIL DAN PEMBAHASAN}

\section{Sikap siswa dalam pembelajaran Matematika}

Hasil penelitian menunjukkan bahwa porsentase siswa yang memiliki sikap "sangat positif" dan "positif" dalam pembelajaran matematika sebesar $52,77 \%$ sedangkan sisanya bersikap "negatif" dan "sangat negatif" dalam pembelajaran matematika seperti terlihat pada tabel 3 .

Tabel 3. Porsentase sikap siswa dalam pembelajaran matematika

\begin{tabular}{ccccc}
\hline No & Kriteria Sikap & $\begin{array}{c}\text { Jumlah } \\
\text { Siswa }\end{array}$ & $\begin{array}{c}\text { Porsentase } \\
\text { (\%) per } \\
\text { kriteria }\end{array}$ & $\begin{array}{c}\text { Porsentase } \\
(\%)\end{array}$ \\
\cline { 1 - 4 } 1 & Sangat Positif & 11 & 15,27 & \multirow{2}{*}{52,77} \\
\hline 2 & Positif & 27 & 37,50 & \\
\hline 3 & Negatif & 24 & 33,34 & \multirow{2}{*}{47,23} \\
\hline 4 & Sangat Negatif & 10 & 13,89 & \\
\hline & Total & 72 & 100 & 100 \\
\hline
\end{tabular}

Porsentase pada tabel 3 menunjukkan bahwa porsentase sikap positif siswa dalam pembelajaran matematika lebih banyak dibandingkan dengan siswa yang bersikap negatif, meskipun dengan selisih porsentase sebesar 5,54\%. Kenyataan ini menunjukkan bahwa secara keseluruhan siswa dapat dikategorikan memiliki sikap yang positif terhadap pembelajaran matematika, tetapi tidak sedikit yang memiliki sikap negatif dalam pembelajaran matematika. Pada umumnya siswa cenderung mengatakan matematika itu sulit, susah, banyak rumus, gurunya galak, menakutkan dan sebagainya (Kartono, 2014). Oleh karena itu, porsentase sikap negatif siswa dalam pembelajaran matematika masih dalam kategori tinggi yaitu sebesar 47,23\%. Masih besarnya porsentase sikap negatif siswa dalam pembelajaran matematika

\section{Sikap siswa laki-laki dalam pembelajaran Matematika}

Porsentase sikap siswa laki-laki dalam pembelajaran matematika secara keseluruhan sebesar 58,33\% yang memiliki sikap "sangat positif" dan "positif". Porsentase tersebut lebih besar dari siswa yang memiliki sikap "negatif" dan "sangat negatif" yaitu sebesar 41,67\%. Artinya siswa laki-laki cenderung memiliki sikap yang positif terhadap pembelajaran matematika meskipun belum memenuhi porsentase minimal yang diharapkan. Secara visual diagram sikap siswa laki-laki pada pembelajaran matematika dapat digambarkan sebagai berikut:

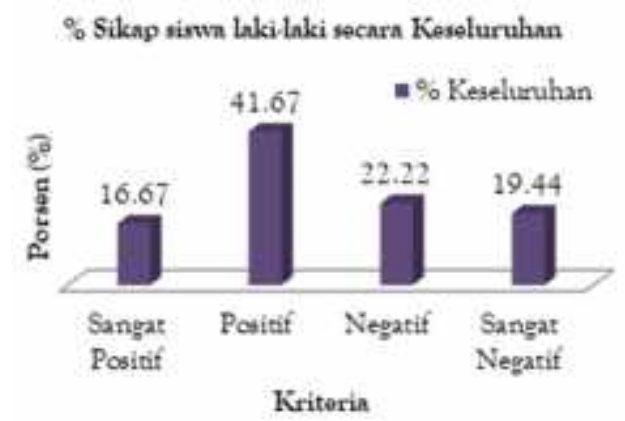

Gambar 1. Porsentase sikap siswa laki-laki dalam pembelajaran matematika

Lebih lanjut, jika dilihat dari tiga dimensi sikap yang diukur yaitu "Jujur (JJR)", "Interaksi Lingkungan (ILN)" dan "Serius (SRS)", maka siswa laki-laki cenderung banyak bersikap "jujur" dalam pembelajaran matematika dibandingkan bersikap "Interaksi Lingkungan" dan "Serius" dalam pembelajaran matematika. Untuk dimensi 
atau sikap "serius" dalam pembelajaran matematika siswa laki-laki memiliki porsentase yang paling rendah. Kenyataan tersebut dapat digambarkan sebagai berikut:

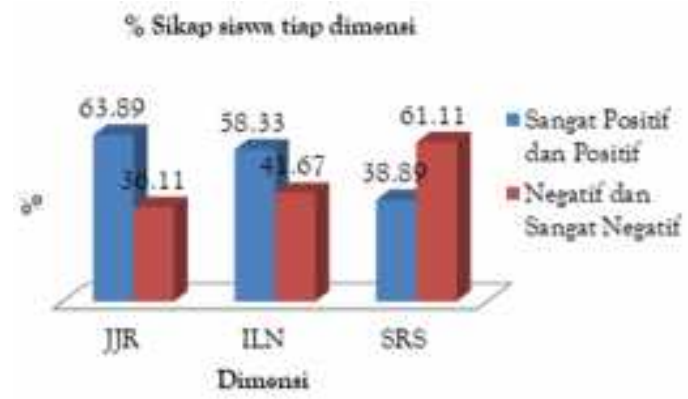

Gambar 2. Porsentase sikap siswa laki-laki dalam pembelajaran matematika tiap dimensi

Dari gambar 2 terlihat bahwa porsentase sikap "sangat positif dan positif" siswa laki-laki dalam pembelajaran matematika adalah sebesar 63,89\% pada dimensi JJR, 58,33\% untuk dimensi ILN dan 38,89\% pada dimensi SRS. Jika diuraikan maka siswa laki-laki cenderung memiliki sikap yang jujur, atentif, efisien, percaya diri dan mudah untuk berinteraksi dengan lingkungan sekitarnya dalam hal pembelajaran matematika dibandingkan bersikap kritis, teliti dan telaten. Hal ini sejalan dengan pendapat (Maccoby, E \& Jacklin, C, 1974) mengatakan laki-laki dan perempuan mempunyai perbedaan kemampuan antara lain sebagai berikut: 1) Perempuan mempunyai kemampuan verbal lebih tinggi dari pada laki-

Tabel 4. Porsentase sikap siswa perempuan dalam pembelajaran matematika

\begin{tabular}{|c|c|c|c|c|c|c|c|c|}
\hline \multirow{3}{*}{ Kriteria } & \multirow{2}{*}{\multicolumn{2}{|c|}{ Sikap Keseluruhan }} & \multicolumn{6}{|c|}{ Sikap Tiap Dimensi } \\
\hline & & & \multicolumn{2}{|c|}{ JJR } & \multicolumn{2}{|c|}{ ILN } & \multicolumn{2}{|c|}{ SRS } \\
\hline & $\%$ & \% Jumlah & $\%$ & \% Jumlah & $\%$ & \% Jumlah & $\%$ & \% Jumlah \\
\hline Sangat Positif & 19.44 & \multirow{2}{*}{47.22} & 16.67 & \multirow{2}{*}{52.78} & 16.67 & \multirow{2}{*}{50.00} & 16.67 & \multirow{2}{*}{66.67} \\
\hline Positif & 27.78 & & 36.11 & & 33.33 & & 50.00 & \\
\hline Negatif & 36.11 & \multirow{2}{*}{52.78} & 19.44 & \multirow{2}{*}{47.22} & 30.56 & \multirow{2}{*}{50.00} & 16.67 & \multirow{2}{*}{33.33} \\
\hline Sangat Negatif & 16.67 & & 27.78 & & 19.44 & & 16.67 & \\
\hline
\end{tabular}

Dari tabel 4 di atas, dapat dijelaskan bahwa pada umumnya siswa perempuan cenderung memiliki sikap yang negatif dalam pembelajaran matematika. Meski demikian, siswa perempuan cenderung memiliki sikap kritis, teliti dan telaten dalam belajar matematika dibandingkan bersikap jujur, atentif, efisien, percaya diri dan berinteraksi dengan lingkungan sekitar. Kondisi tersebut sejalan dengan pendapat Krutetski (Nafi'an, 2011) menjelaskan perbedaan antara laki. 2) Laki-laki lebih unggul dalam kemampuan visual spatial (penglihatan keruangan) dari pada perempuan. 3) Laki-laki lebih unggul dalam kemampuan matematika.

\section{Sikap siswa perempuan dalam pembelajaran Matematika}

Berbeda dengan siswa laki-laki, porsentase sikap siswa perempuan dalam pembelajaran matematika menunjukkan perbedaan yang signifikan. Secara keseluruhan siswa perempuan memiliki sikap "sangat positif dan positif" dalam pembelajaran matematika dengan porsentase sebesar 47,22\%, sedangkan sisanya sebesar $52,78 \%$ memiliki sikap "negatif dan sangat negatif”. Dapat dikatakan bahwa siswa perempuan kurang memiliki sikap yang positif dalam pembelajaran matematika. Apabila dilihat dari tiap dimensi porsentase sikap siswa perempuan memiliki porsentase yang cukup baik pada tiap dimensinya. Pada dimensi JJR, sikap siswa yang "sangat positif dan positif" adalah sebesar 52,78\%, dimensi ILN sebesar 50\% dan dimensi SRS sebesar 66,67\%. Artinya siswa perempuan memiliki sikap lebih "serius" dalam pembelajaran matematika dibandingkan dengan sikap "Interaksi Lingkungan dan Jujur". Pernyataan tersebut selengkapnya dapat dilihat pada tabel 4 berikut: laki-laki dan perempuan dalam belajar matematika sebagai berikut: 1) Laki-laki lebih unggul dalam penalaran, perempuan lebih unggul dalam ketepatan, ketelitian, kecermatan, dan keseksamaan berpikir. 2) Laki-laki memiliki kemampuan matematika dan mekanika yang lebih baik dari pada perempuan, perbedaan ini tidak nyata pada tingkat sekolah dasar akan tetapi menjadi tampak lebih jelas pada tingkat yang lebih tinggi. Pendapat tersebut 
menunjukkan kemampuan yang tinggi bagi anak laki-laki dalam hal matematika, namun perempuan lebih unggul dalam aspek efektifnya (tekun, teliti, cermat) (Z. Amir, 2013).

\section{Sikap siswa laki-laki dan perempuan dalam pembelajaran Matematika}

Berdasarkan analisis data yang diperoleh, maka dapat dilihat beberapa perbedaan porsentase sikap siswa laki-laki dan perempuan dalam pembelajaran matematika. Perbedaan sikap yang dimaksud dipandang dari dimensi sikap satu per satu dan sikap secara keseluruhan. Berikut diagram perbedaan yang dimaksud.

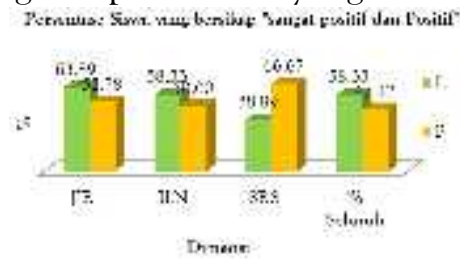

Gambar 3. Porsentase sikap siswa laki-laki dan perempuan dalam pembelajaran matematika

Berdasarkan gambar 3 dapat dideskripsikan beberapa hal, yaitu: 1) siswa laki-laki memiliki sikap lebih jujur (JJR) dibanding siswa perempuan dalam pembelajaran matematika dengan selisih $11,11 \%, 2$ ) siswa laki-laki lebih cenderung mampu berinteraksi dengan lingkungan (ILN) dibanding siswa perempuan dalam pembelajaran matematika meskipun dengan selisih porsentase sebesar 8,33\%, dan 3) siswa perempuan cenderung memiliki sikap lebih serius (SRS) dalam pembelajaran matematika dibanding siswa laki-laki dengan selisih porsentase sebesar $27,78 \%$. Jika dilihat secara keseluruhan untuk semua dimensi, maka sikap siswa laki-laki terhadap pembelajaran matematika cenderung lebih positif dibandingkan sikap siswa perempuan dengan selisih porsentase $11,11 \%$ atau sebanyak 8 siswa.

Sikap jujur (JJR) siswa meliputi sikap jujur dan atentif dalam pembelajaran matematika, artinya siswa laki-laki memiliki tingkat kejujuran yang lebih baik dibanding siswa perempuan dalam hal pembelajaran matematika. Selain itu, siswa laki-laki juga cenderung memiliki sikap atentif (perhatian) yang lebih baik dibanding siswa perempuan dalam pembelajaran matematika. Kenyataan yang sama juga terjadi pada sikap Interaksi dengan Lingkungan (ILN) yang meliputi sikap efisien, interaksi lingkungan dan percaya diri, dimana sikap-sikap tersebut masih diungguli siswa laki-laki dalam hal pembelajaran matematika. Meski demikian, sikap Serius (SRS) yang meliputi sikap kritis, teliti dan telaten dalam pembelajaran matematika sangat jauh diungguli oleh siswa perempuan dibanding siswa laki-laki dengan selisih porsentase jumlah yang paling banyak dibanding pada sikap-sikap yang lain.

Menurut American Psychological Association (2010) (Nafi'an, 2011) , mengemukakan berdasarkan analisis terbaru dari penelitian internasional kemampuan perempuan di seluruh dunia dalam matematika tidak lebih buruk dari pada kemampuan laki laki meskipun laki-laki memiliki kepercayaan diri yang lebih dari perempuan dalam matematika, dan perempuanperempuan dari negara dimana kesamaan gender telah diakui menunjukkan kemampuan yang lebih baik dalam tes matematika (Nafi'an, 2011). Selanjutnya, (Anggreini, 2013) menyatakan bahwa faktor-faktor yang memengaruhi kecemasan siswa dalam menghadapi mata pelajaran matematika adalah jenis kelamin, usia dan kelas, siswa pria cenderung lebih cemas dalam menghadapi mata pealajaran matematika dibandingkan dengan siswa wanita. Namun hasil penelitian oleh (Judith, Allan \& Meece Wigfield, 1988) yang menilai perbedaan usia dan gender, renspon dari siswa lelaki dan perempuan melalui MAQ disimpulkan bahwa Sikap negatif (kecemasan) siswa perempuan terhadap matematika lebih kuat dari siswa lelaki pada tingkat usia 6, 7, 9, dan 11 tahun. Meskipun dari segi usia belum memenuhi usia siswa SMP, hasil penelitian tersebut cukup memberikan gambaran terhadap sikap siswa laki-laki dan perempuan dalam pembelajaran matematika.

\section{KESIMPULAN}

Secara keseluruhan, sikap siswa SMP dalam pembelajaran matematika dapat dikategorikan positif meskipun dengan selisih porsentase yang kecil. Sikap positif ini didominasi oleh siswa lakilaki pada ketiga dimensi atau delapan sikap yang diukur. Hal ini dipertegas dari hasil penelitian 
bahwa siswa laki-laki cendrung lebih mampu bersikap jujur, atentif, efisien, percaya diri dan interaksi dengan lingkungan dibandingkan siswa perempuan dalam pembelajaran matematika. Tetapi, siswa perempuan jauh lebih mampu bersikap kritis, teliti dan telaten dibandingkan siswa laki-laki.

\section{REFERENSI}

Anggreini, T. (2013). Hubungan Antara kecemasan Dalam Menghadapi Mata Pelajaran Matematika Dengan Prestasi Akademik Matematika Pada Remaja.

Azwar, S. (2013). Sikap Manusia dan Pengukurannya (2nd ed.). Yogyakarta: Pustaka Pelajar.

Gomes, I. . \& C. (2001). Affective Influences In The Knowledge Of. Educational Studies in Mathematics, 43:, 149-168.

Hidayad, A. (2017). Instrumen Asesmen Sikap Siswa Berbasis Konservasi pada Pembelajaran Matematika SMP. Journal of Educational Research and Evaluation, 6(1), 3038.

Judith, Allan \& Meece Wigfield, L. (1988). Math Anxiety in Elementary and Secondary School Students. Journal of Educational Psychology, 80, 210-216.

Kartono. (2014). Renovasi Citra Karakteristik Afektif Siswa Untuk Pembelajaran Matematika Sekolah Melalui Asesmen. Semarang: Universitas Negeri Semarang.

Maccoby, E \& Jacklin, C, N. (1974). The Psychology of Sex Differences. Stanford: Stanford University.

Mardapi, D. (2008). Teknik Penyusunan Instrumen Tes dan Non tes (2nd ed.). Yogyakarta: Mitra Cendekia Press.

MARIAMAH. (2017). Efektivitas Pendekatan Pembelajaran Matematika Realistik (PMR) Terhadap Penguasaan Materi Siswa SMP Negeri 8 Kota Bima. Pendidikan MIPA, 7(2).

Nafi'an, M. I. (2011). Kemampuan Siswa Dalam Menyelesaikan Soal Cerita Ditinjau Dari Gender Di Sekolah Dasar. Jurnal Pendidikan Matematika FMIPA UNY, (Desember).

Popham, W. J. (1995). Classroom Assessment.
Boston: Allyn and Bacon.

Stiggins, R. (2005). Student-involved assessment for learning. Upper Saddle River, NJ: Pearson.

Z. Amir. (2013). Perspektif Gender dalam Pembelajaran Matematika. Jurnal Marwah, XII (Juni). 